\title{
Differential expression of genes during mastitis in Holstein-Zebu crossbreed dairy cows
}

\author{
I. Fonseca', G.R. Antunes' ${ }^{2}$ D.S. Paiva ${ }^{2}$, C.C. Lange ${ }^{3}$, S.E.F. Guimarães ${ }^{1}$ \\ and M.F. Martins ${ }^{3}$ \\ ${ }^{1}$ Departamento de Zootecnia, Universidade Federal de Viçosa, Viçosa, MG, Brasil \\ ${ }^{2}$ Faculdade de Farmácia, Universidade Federal de Juiz de Fora, \\ Juiz de Fora, MG, Brasil \\ ${ }^{3}$ Embrapa Gado de Leite, Juiz de Fora, MG, Brasil \\ Corresponding author: M.F. Martins \\ E-mail: mmartins@cnpgl.embrapa.br
}

Genet. Mol. Res. 10 (3): 1295-1303 (2011)

Received October 8, 2010

Accepted December 12, 2010

Published July 5, 2011

DOI 10.4238/vol10-3gmr1096

\begin{abstract}
Among the potential public health problems of animal production, infectious-contagious diseases stand out. Mastitis is among the main diseases affecting dairy cattle. One of the most promising options to reduce the problems caused by this disease, besides proper sanitary and management practices, is selective breeding of resistant animals. To shed light on the immune response mechanisms involved in the resistance/susceptibility phenotype to this disease, we quantified the relative expression of the genes $I L-2$, $I L-6, I L-8, I L-12, I F N-\gamma, T N F-\alpha, T L R-2, S E M A 5 A$, and FEZL in cells of crossbreed dairy cows, divided into two groups, one healthy and the other suffering from clinical mastitis. Total RNA was extracted from the cells in the milk from the animals in each group (with and without clinical mastitis). Gene expression was determined using the real-time PCR method. The levels of gene expression were compared, and the cows with mastitis were found to express 2.5
\end{abstract}


times more $T L R-2$ than those free of mastitis $(\mathrm{P}<0.05)$. There were no significant differences in the expression of the other genes.

Key words: Immune response; Real-time PCR; Resistance to mastitis; Toll-like receptor 2 gene

\section{INTRODUCTION}

Dairy cattle breeds of European origin are recognized as being more productive and also more demanding in terms of management and nutrition than are Zebu breeds. Therefore, the expected higher production is not always borne out in tropical regions on dairy farms that are less technically advanced, since the animals do not receive sufficient management and nutrition to reach their full genetic potential. The use of crossbreed cattle to produce milk, in a pasture-based system, is a common option among dairy farmers in Brazil and other tropical regions. Various crosses of European and Zebu breeds are capable of profitably and sustainably, producing milk under tropical conditions. These animals thus make up an important contingent of Brazil's dairy herds: an estimated $70 \%$ of the country's milk comes from Holstein-Zebu crossbreeds (Embrapa Gado de Leite, 2003).

In recent decades, the dairy production chain in Brazil has undergone intense transformations, with restructuring of all links, making the sector more competitive. This is reflected in the $70 \%$ increase in productivity (liters/cow/year) between 1980 and 2007 (Embrapa Gado de Leite, 2008). Although the statistics show continuous development, there are still various obstacles that need to be overcome, particularly by smaller, less technically advanced dairy operators, to be able to maintain the sector's sustainability and competitiveness. Several factors affect dairy production, such as climate, installations, herd health, labor availability and zootechnical and genetic potential. Among animal health problems, infectious-contagious diseases stand out the most, and mastitis is the main such disease afflicting dairy cattle from an economic standpoint (Oviedo-Boyso et al., 2007).

One of the most promising ways to reduce the problems caused by mastitis, besides adequate sanitary conditions, is the selective breeding of resistant animals. According to Detilleux et al. (1994), it is hard to produce effective vaccines against this disease due to the large variety of microorganisms causing it and its multifactor character. Therefore, studies to better understand the biological processes involved in determining resistance to diseases are essential to resolve problems and develop innovative solutions.

Mastitis is one of the most prevalent and costly diseases affecting the dairy industry worldwide (Bradley, 2002; Petrovski et al., 2006). It is characterized by inflammation of the mammary gland and is generally caused by bacteria. The speed and efficacy of the host's immune response to the invading microorganisms is a crucial factor for the establishment, persistence and severity of the infection (Bannerman et al., 2009). Epithelial and endothelial cells perform important functions in the first-line defense against local infections, by producing cytokines and other inflammatory mediators (Strandberg et al., 2005; Corl et al., 2008; Griesbeck-Zilch et al., 2008). In the mammary gland, cells from the immune system together with epithelial cells are responsible for recognizing the invading microorganism via Toll-like receptors, or TLRs (Rainard and Riollet, 2006; Griesbeck-Zilch et al., 2008). Activation of TLRs triggers the expression of inflammatory cytokines and other mediators related to immune response, cell differentiation and apoptosis (Ibeagha-Awemu et al., 2008; Yang et al., 2008; Cates et al., 2009).

The importance of inflammatory cytokines to the development of an effective immune 
response against mastitis has been documented in several researchs, which have evaluated changes in their concentrations in milk during tests on animals with experimentally infected udders (Burvenich et al., 2003; Bannerman et al., 2009). The resistance response to mastitis is a complex characteristic and the genes involved in the immune response have been indicated as strong candidates in determining animal resistance (Shuster et al., 1993; Ferens et al., 1998; Alluwaimi et al., 2003; Rambeaud et al., 2003; Oviedo-Boyso et al., 2007; Fonseca et al., 2009). In light of this premise, the aim of this study was to characterize the expression of genes related to the phenotype determining resistance/susceptibility to mastitis, to better understand the immune response mechanisms. For this purpose, we carried out field tests to investigate the expression of the following genes: $I L-2$ (interleukin 2), $I L-6$ (interleukin 6), $I L-8$ (interleukin 8), $I L-12$ (interleukin 12), $I F N-\gamma$ (interferongamma), TNF- $\alpha$ (tumor necrosis factor-alpha), TLR-2 (Toll-like receptor 2), SEMA5A (semaphorin $5 \mathrm{~A}$ ), and FEZL (forebrain embryonic zinc-finger-like) in cells present in the milk of crossbreed cows (Holstein x Gyr) with and without clinical mastitis, using naturally infected animals.

\section{MATERIAL AND METHODS}

We used 20 crossbreed cows from the Santa Mônica Experimental Field of the Embrapa Dairy Cattle Research Unit, located in the municipality of Valença in the State of Rio de Janeiro. We selected two groups, one free of infection and the other with clinical mastitis, each composed of 10 animals with different birth orders, blood degree and age.

All animals underwent clinical udder examination and strip-cup testing before collection of the milk samples. From each cow, $200 \mathrm{~mL}$ milk was taken in sterile tubes. The milk samples from the cows with mastitis were collected immediately after the appearance of clinical signs and before treatment with drugs. Hence, there was no artificial infection or treatment effect. Additionally, all the samples from cows with mastitis were submitted to microbiological tests to identify the pathogen, performed according to NMC (1987).

Total RNA of the milk samples was extracted using the RNeasy ${ }^{\circledR}$ Mini Kit (Qiagen, Valencia, CA, USA), following manufacturer recommendations. To remove any contamination by genomic DNA, the samples were submitted to digestion with DNase (RNase-free DNase Set, Qiagen). The quality of the RNA samples was evaluated by the Agilent Bioanalyzer 2100 (Agilente, Palo Alto, CA, USA) and the concentrations were determined by spectrophotometry using a NanoDrop ND-1000 device (NanoDrop Technologies, Wilmington, DE, USA). The mean RNA integrity index of the samples was 6.3 (data not shown).

The first cDNA strand was synthesized using the SuperScript ${ }^{\mathrm{TM}}$ III First-Strand Synthesis SuperMix kit (Invitrogen, Carlsbad, CA, USA), and the average DNA concentrations were estimated by spectrophotometry, after which the single cDNA strand was stored at $-20^{\circ} \mathrm{C}$ until use in the real-time polymerase chain reaction (qPCR).

The qPCRs were carried out with the SYBR Green ${ }^{\circledR}$ PCR Master Mix kit (Applied Biosystems, Foster City, CA, USA), according to manufacturer recommendations. The primers used to evaluate the gene expressions were designed according to data from the literature, as shown in Table 1.

Six endogenous controls were used: $\beta$-actin, $18 S$ rRNA, GAPDH (glyceraldehyde-3-phosphate dehydrogenase), Ubiquitin, RPLPO (ribosomal protein, large P0), and HPRT (hypoxanthineguanine phosphoribosyltransferase). We chose the two best endogenous controls according to the profile of the amplification and dissociation curves, and also analyzed them with the geNorm soft- 


\begin{tabular}{llll}
\multicolumn{2}{l}{ Table $\mathbf{1 .}$ Primer sequences used in the qPCRs. } & & Reference \\
\hline Gene & Primer $\mathrm{F}$ & Primer R & Leutenegger et al., 2000 \\
\hline$I L-2$ & GGATTTACAGTTGCTTTTGGAGAAA & GCACTTCCTCTAGAAGTTTGAGTTCTT & Leutenegger et al., 2000 \\
$I L-6$ & TCAGCTTATTTCTGCCAGTCTCT & TCATTAAGCACATCGTCGACAAA & Leutenegger et al., 2000 \\
$I L-8$ & CACTGTGAAAAATTCAGAAATCATTGTTA & CTTCACCAAATACCTGCACAACCTTC & Leutenegger et al., 2000 \\
$I L-12$ & TTAATTGAGGTCGTGGTAGAAGCTG & GGTCTCAGTTGCAGGTTCTTGG & Leutenegger et al., 2000 \\
$I F N-\gamma$ & TGGATATCATCAAGCAAGACATGTT & ACGTCATTCATCACTTTCATGAGTTC & Leutenegger et al., 2000 \\
$T N F-\alpha$ & TCTTCTCAAGCCTCAAGTAACAAGT & CCATGAGGGCATTGGCATAC & Ibeagha-Awemu et al., 2008 \\
$T L R-2$ & CAGTTTAACCCAGTGCTTC & CTCCAACGTCTTCAGTTGCT & Sugimoto et al., 2006 \\
SEMASA & TGTGGGACCAACGCTTTCA & TCATGGATCTCCGTCAGGTTACT & Sugimoto et al., 2006 \\
$F E Z L$ & CTACAAGCCCTTCGTCTGTGAAT & GCTGTGGGTCAGCTTGTGATT & Wang et al., 2005 \\
$18 S r R N A$ & GTAACCCGTTGAACCCCATT & CCATCCAATCGGTAGTAGCG & Mount et al., 2009 \\
GAPDH & CCTGGAGAAACCTGCCAAGT & GCCAAATTCATTGTCGTACCA & Singh et al., 2008 \\
Ubiquitin & GGCAAGACCATCACCCTGGAA & GCCACCCCTCAGACGAAGGA & Mount et al., 2009 \\
$R P L P O$ & CAACCCTGAAGTGCTTGACAT & AGGCAGATGGATCAGCCA & Tao et al., 2004 \\
$H P R T$ & GCCGACCTGTTGGATTACAT & ACACTTCGAGGGGTCCTTTT & \\
\hline
\end{tabular}

ware (Vandesompele et al., 2002). After 40 amplification cycles, all the samples were submitted to dissociation curve analysis to verify the absence of non-specific products and primer dimers.

After real-time quantification, the reactions were optimized for all the genes, by testing three quantities of cDNA $(100,200$ and $400 \mathrm{ng} /$ reaction $)$ and six primer dilutions $(50,100,200,400$, 600 , and $900 \mathrm{nM}$ ). After determining the best conditions, we plotted the standard curve for each gene, in which each series cDNA dilution was graphed against the respective $\mathrm{Ct}$ (cycle threshold).

Each test was performed in duplicate in optical 96-well reaction plates, sealed with optical adhesive film and amplified in an ABI Prism 7300 Sequence Detection Systems device (Applied Biosystems), with each target amplified separately. The data obtained from the qPCRs, generated by the device, were analyzed by the REST ${ }^{\circ} 2009$ program, developed by M. Pfaffl (Technical University of Munich) and by Qiagen, available at http://www.gene-quantification. de/rest-2009.html, to compare the expression difference between the treatments.

Table 2 shows the amplification sequence for each gene. In the dissociation curves, two peaks could be observed for $G A D P H$ in the samples from two animals, so this primer was excluded from the analyses by the geNorm software to choose the best endogenous control. For the other genes, no peaks were observed referring to primer dimers or non-specific products (data not shown). Table 2 also shows the quantity of cDNA and primer optimized for

\begin{tabular}{|c|c|c|c|c|}
\hline Gene & Primer $(\mathrm{nM})$ & cDNA (ng/reaction) & Efficiency & DT $\left({ }^{\circ} \mathrm{C}\right)$ \\
\hline$I L-2$ & 400 & 400 & 0.7 & 75.9 \\
\hline$I L-6$ & 400 & 400 & 0.8 & 76.1 \\
\hline$I L-8$ & 400 & 100 & 0.8 & 76.6 \\
\hline$I L-12$ & 200 & 200 & 0.9 & 76.7 \\
\hline$T N F-\alpha$ & 400 & 200 & 0.8 & 82.5 \\
\hline$I F N-\gamma$ & 400 & 100 & 0.9 & 77.8 \\
\hline$T L R-2$ & 50 & 200 & 0.9 & 75.3 \\
\hline SEMA5A & 900 & 400 & 0.7 & 74.3 \\
\hline$F E Z L$ & 900 & 400 & 0.7 & 80.6 \\
\hline $18 S \mathrm{rRNA}$ & 200 & 100 & 0.9 & 80.7 \\
\hline GAPDH & 200 & 200 & 1.0 & 83.3 \\
\hline Ubiquitin & 200 & 100 & 0.9 & 83.4 \\
\hline$R P L P O$ & 400 & 200 & 1.0 & 83.2 \\
\hline$H P R T$ & 400 & 200 & 0.9 & 78.6 \\
\hline
\end{tabular}


each gene, besides the dissociation temperature of the amplified fragment. The coefficient of variation of the duplicate $\mathrm{Ct}$ readings for each sample did not exceed 5\% (data not shown).

The analyses with the geNorm software indicated that the two most efficient endogenous controls were $18 S$ rRNA and Ubiquitin, as can be seen in Figure 1, because these showed the lowest expression variation among the animals.

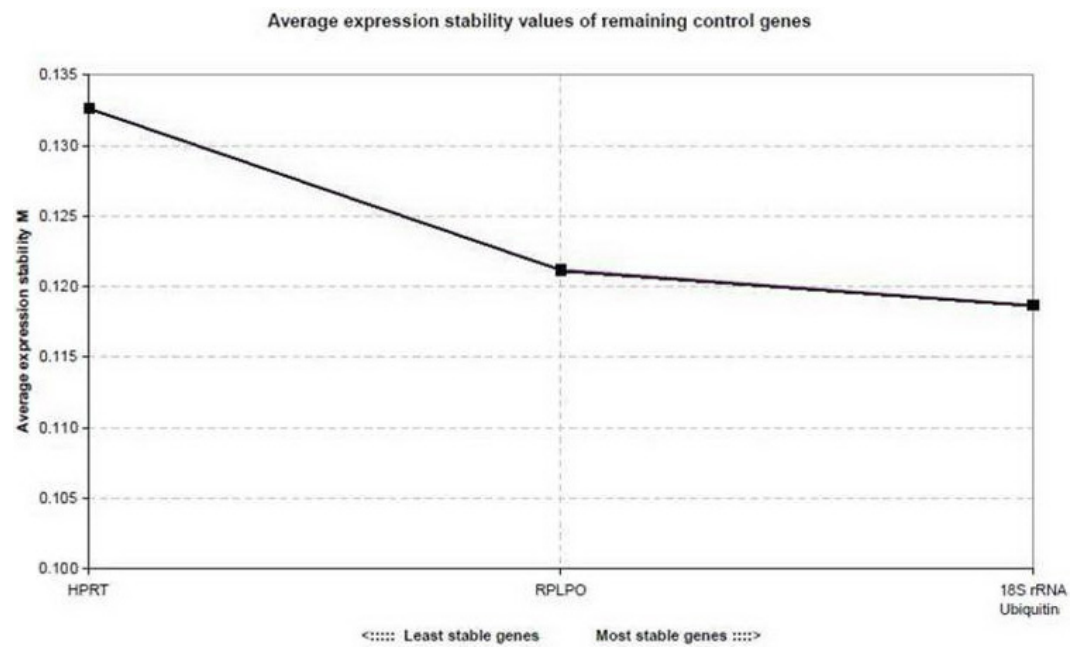

Figure 1. Result of the best endogenous control analysis, performed with the geNorm software. $H P R T=$ hypoxanthine-guanine phosphoribosyltransferase; $R P L P 0=$ ribosomal protein, large $\mathrm{P} 0$.

\section{RESULTS}

Table 3 shows the results of the microbiological examination of cows with mastitis, according to which three cows were infected by Corynebacterium spp, three by Streptococcus agalactiae, one by Streptococcus spp, and one by coagulase-negative Staphylococcus spp. No bacterial growth was detected in the milk of the other two cows, even though the animals showed clinical signs of mastitis. Reports indicate that $25-40 \%$ of all clinical samples are negative on routine culture. The number of the organism less than the minimum detection limit of the assay, the absence of the microorganism in the sample, or phagocytosis of the microorganism by somatic cells may be some of the reasons for these cases (NMC, 1987).

\begin{tabular}{llc}
\multicolumn{2}{c}{ Table 3. Results of the microbiological examination of animals with clinical mastitis. } \\
\hline Animal & Microbiological test & Gram classification \\
\hline $0642-0$ & Negative result & - \\
0797 & Corynebacterium spp & Gram-positive \\
$0801-0$ & Corynebacterium spp & Gram-positive \\
$0860-0$ & Corynebacterium spp & Gram-positive \\
1759 & Negative result & - \\
3604 & Streptococcus agalactiae & Gram-positive \\
3754 & Streptococcus spp & Gram-positive \\
4523 & Coagulase negative Staphylococcus spp & Gram-positive \\
$8726-9$ & Streptococcus agalactiae & Gram-positive \\
9838 & Streptococcus agalactiae & Gram-positive \\
\hline
\end{tabular}


We also compared the gene expression level of the crossbreed animals with and without clinical mastitis (Table 4). The expression in the animals with mastitis was 2.5 times greater for $T L R-2$ than in the animals without mastitis $(\mathrm{P}<0.05)$. There was no significant difference in expression for the other genes $(\mathrm{P}>0.05)$ according to the analyses carried out with the REST $^{\circ} 2009$ program.

Table 4. Relative expression of the genes in crossbreed cows with mastitis in relation to the animals without mastitis.

\begin{tabular}{lccc}
\hline Gene & Relative expression & Standard error & Probability \\
\hline$I L-2$ & 0.687 & $0.062-6.007$ & 0.618 \\
$I L-6$ & 0.763 & $0.043-6.571$ & 0.707 \\
$I L-8$ & 1.409 & $0.168-8.271$ & 0.620 \\
$I L-12$ & 0.514 & $0.031-6.668$ & 0.449 \\
$T N F-\alpha$ & 0.551 & $0.159-2.153$ & 0.226 \\
$I F N-\gamma$ & 0.459 & $0.050-2.674$ & 0.213 \\
$T L R-2 *$ & 2.504 & $0.645-8.691$ & 0.047 \\
$S E M A 5 A$ & 0.476 & $0.036-5.020$ & 0.350 \\
$F E Z L$ & 0.476 & $0.034-4.677$ & 0.325 \\
\hline
\end{tabular}

Numbers greater than $1=$ greater expression in animals with mastitis; numbers less than $1=$ lower expression in animals with mastitis $(* \mathrm{P}<0.05)$.

\section{DISCUSSION}

Innate immunity predominates in the initial phase of infection and is mediated by macrophages, neutrophils, natural killer cells, and cytokines. It recognizes and responds to different pathogens, even if the organism has never been infected by the particular species. Bacteria are especially likely to have different cell wall structures, which are recognized by membrane receptors. These structures are lipopolysaccharides, peptidoglycans (PGN) and lipoteichoic acid (LTA), which constitute the pathogen-associated molecular patterns (PAMPs). These PAMPs are recognized by TLRs, which are located in the cell and endosome membranes. Interaction between the PAMPs and TLRs of immune system cells induces the production of cytokines and other endogenous mediators, which are essential for protecting the organism against pathogenic microorganisms. The TLR-2 gene is responsible for recognizing the LTA and PGN of Grampositive bacteria (Hirschfeld et al., 2000; Takeuchi et al., 2000). As can be observed in Table 2, all the microorganisms identified as causing mastitis in this study are Gram-positive bacteria. This corroborates other findings reported in the literature, according to which there was greater expression of the TLR-2 gene during mastitis caused by Gram-positive microorganisms (Bannerman et al., 2004a; Goldammer et al., 2004; Swanson et al., 2009).

We did not observe significant differences $(\mathrm{P}>0.05)$ between the groups studied in relation to the expression level of the other genes. The $I L-2$ gene, produced mainly by $\mathrm{Th}_{1}$ lymphocytes, induces the proliferation of mononuclear cells and activates some epithelial cells. In contrast, $I F N-\gamma$ is associated with conversion of $\mathrm{Th}_{0}$ into $\mathrm{Th}_{1}$ lymphocytes and activation of macrophages, as well as potentiating the action of TNF- $\alpha$ (Janeway et al., 2002). Therefore, this cytokine is related to the $\mathrm{Th}_{1}$ immune response profile, i.e., the immune response of this cell type. The $I L-8$ gene, together with $I L-1$ and $T N F-\alpha$, has been indicated as an important mediator of neutrophil recruitment to the inflamed site. Some studies have shown that TNF- $\alpha$ and IL- 8 are present in the milk from udders infected by Gram-negative bacteria, such as Escherichia coli, Klebsiella pneumoniae or Pseudomonas aeruginosa, but they are present in 
lower concentrations or not detected in the milk from cows with mammary glands infected by Staphylococcus aureus (Shuster et al., 1997; Riollet et al., 2000; Bannerman et al., 2004a,b, 2005). Another study by our group with commercial cattle with and without mastitis caused by natural infection showed a difference in the expression profile of the $I F N-\gamma, I L-2$ and $I L-10$ genes among animals of the Holstein BW and Gyr breeds (Fonseca et al., 2009).

Despite the non-significant expression for the other genes, these results improve the understanding of how immunological reactions occur in response to mastitis, greatly affecting milk quality and quantity, especially in crossbreed animals, which are the basis of the dairy industries in Brazil. Mastitis is a multifactor disease and resistance is influenced by many genes. For this reason, gene-expression studies are particularly important to clarify how immune responses to this disease occur. The present study is groundbreaking in this respect for studying crossbreed animals. The majority of studies have examined European breeds with artificially induced infection. Like this study, that by Fonseca et al. (2009) also evaluated the expression of some genes in naturally infected cows, but of separate Holstein BW and Gyr breeds rather than crossbreed animals. In that study, the $I L-6, I L-8$ and $T N F-\alpha$ genes also failed to show significantly different expression between cows with and without clinical mastitis.

The immune response can differ according to the bacterial strain and the host, because there is great individual variation. Lahouassa et al. (2007) demonstrated, by means of in vitro studies, that different strains of $S$. aureus provoke different responses in epithelial cells and the udder. Besides this, the intensity and level of expression of the genes considered in that study (IL- $8, G R O-\alpha, G R O-\beta, T N F-\alpha, I L-1 \beta, T G F-\beta 1$, and $I L-10)$ varied according to the infection phase $(3,10$ and $24 \mathrm{~h}$ after addition of the bacteria to the cell culture). According to the authors, these different responses imply alternate activation pathways or different levels of signal transduction, reflecting what is observed in vivo. Swanson et al. (2009) also showed that after infection of the udder by a pathogen, complex cellular and physiological processes occur, and the changes in the expression of genes related to the immune response by epithelial cells in the mammary gland appear to be specific for each pathogen. These articles highlight the complexity of the immune response to an infective pathogen. In the present study, the milk samples were collected just after the detection of clinical signs of natural infection, so there was no control of the time of infection. Besides this, there was no control of the type of strain that caused the infection, and in two cows it was not even possible to isolate the pathogen. It should be pointed out that this study was an attempt to demonstrate what happens in a commercial herd under natural conditions, and thus, it is not possible to state that these animals were free of other infections or diseases that could have influenced the results.

From the results of this study, we cannot affirm that the genes studied are only expressing the messenger RNA or are also expressing a protein, since there are post-transcriptional regulation factors that were not analyzed. For this reason, it would be interesting to perform proteomic studies to better understand these results. Besides this, the analysis of the structure of the TLR-2 gene, which showed a significant difference in expression, could be useful to identify SNP markers for mastitis resistance and susceptibility phenotypes in crossbreed animals.

It was possible to verify the difference in the expression profile of the $T L R-2$ gene in relation to the mastitis resistance/susceptibility phenotype among the animals examined. We intend to perform further studies including a larger number of samples and specific experimental conditions, to evaluate the potential of the TLR-2 gene as a marker, and also to include new genes, so as to obtain a better understanding of the physiopathological mechanisms of mastitis. 


\section{ACKNOWLEDGMENTS}

Research supported by FAPEMIG. We are grateful to M.M. Junqueira and C. Freitas for sample collection.

\section{REFERENCES}

Alluwaimi AM, Leutenegger CM, Farver TB, Rossitto PV, et al. (2003). The cytokine markers in Staphylococcus aureus mastitis of bovine mammary gland. J. Vet. Med. B. Infect. Dis. Vet. Public Health 50: 105-111.

Bannerman DD, Paape MJ, Lee JW, Zhao X, et al. (2004a). Escherichia coli and Staphylococcus aureus elicit differential innate immune responses following intramammary infection. Clin. Diagn. Lab. Immunol. 11: 463-472.

Bannerman DD, Paape MJ, Hare WR and Hope JC (2004b). Characterization of the bovine innate immune response to intramammary infection with Klebsiella pneumoniae. J. Dairy Sci. 87: 2420-2432.

Bannerman DD, Chockalingam A, Paape MJ and Hope JC (2005). The bovine innate immune response during experimentally-induced Pseudomonas aeruginosa mastitis. Vet. Immunol. Immunopathol. 107: 201-215.

Bannerman DD, Rinaldi M, Vinyard BT, Laihia J, et al. (2009). Effects of intramammary infusion of cis-urocanic acid on mastitis-associated inflammation and tissue injury in dairy cows. Am. J. Vet. Res. 70: 373-382.

Bradley A (2002). Bovine mastitis: an evolving disease. Vet. J. 164: 116-128.

Burvenich C, Van M, V, Mehrzad J, Diez-Fraile A, et al. (2003). Severity of E. coli mastitis is mainly determined by cow factors. Vet. Res. 34: 521-564.

Cates EA, Connor EE, Mosser DM and Bannerman DD (2009). Functional characterization of bovine TIRAP and MyD88 in mediating bacterial lipopolysaccharide-induced endothelial NF-kappaB activation and apoptosis. Comp. Immunol. Microbiol. Infect. Dis. 32: 477-490.

Corl CM, Gandy JC and Sordillo LM (2008). Platelet activating factor production and proinflammatory gene expression in endotoxin-challenged bovine mammary endothelial cells. J. Dairy Sci. 91: 3067-3078.

Detilleux JC, Koehler KJ, Freeman AE, Kehrli ME Jr, et al. (1994). Immunological parameters of periparturient Holstein cattle: genetic variation. J. Dairy Sci. 77: 2640-2650.

Embrapa Gado de Leite (2003). Sistema de Produção de Leite (Zona da Mata Atlântica). Available at [http://sistemasdeproducao. cnptia.embrapa.br/FontesHTML/Leite/Leite ZonadaMataAtlantica/racas1.html]. Accessed October 5, 2009.

Embrapa Gado de Leite (2008). Estatística do Leite. Available at [http://www.cnpgl.embrapa.br/nova/informacoes/ estatisticas/producao/tabela0230.php]. Accessed October 5, 2009.

Ferens WA, Goff WL, Davis WC, Fox LK, et al. (1998). Induction of type 2 cytokines by a staphylococcal enterotoxin superantigen. J. Nat. Toxins. 7: 193-213.

Fonseca I, Silva PV, Lange CC and Guimarães MFM (2009). Expression profile of genes associated with mastitis in dairy cattle. Genet. Mol. Biol. 32: 776-781.

Goldammer T, Zerbe H, Molenaar A, Schuberth HJ, et al. (2004). Mastitis increases mammary mRNA abundance of betadefensin 5, toll-like-receptor 2 (TLR2), and TLR4 but not TLR9 in cattle. Clin. Diagn. Lab. Immunol. 11: 174-185.

Griesbeck-Zilch B, Meyer HH, Kuhn CH, Schwerin M, et al. (2008). Staphylococcus aureus and Escherichia coli cause deviating expression profiles of cytokines and lactoferrin messenger ribonucleic acid in mammary epithelial cells. $J$. Dairy Sci. 91: 2215-2224.

Hirschfeld M, Ma Y, Weis JH, Vogel SN, et al. (2000). Cutting edge: repurification of lipopolysaccharide eliminates signaling through both human and murine toll-like receptor 2. J. Immunol. 165: 618-622.

Ibeagha-Awemu EM, Lee JW, Ibeagha AE, Bannerman DD, et al. (2008). Bacterial lipopolysaccharide induces increased expression of toll-like receptor (TLR) 4 and downstream TLR signaling molecules in bovine mammary epithelial cells. Vet. Res. 39: 11.

Janeway CA, Tavers P, Walport M and Sholmchik MJ (2002). Imunologia: o Sistema Imune na Saúde e na Doença. Artmed, Porto Alegre.

Lahouassa H, Moussay E, Rainard P and Riollet C (2007). Differential cytokine and chemokine responses of bovine mammary epithelial cells to Staphylococcus aureus and Escherichia coli. Cytokine 38: 12-21.

Leutenegger CM, Alluwaimi AM, Smith WL, Perani L, et al. (2000). Quantitation of bovine cytokine mRNA in milk cells of healthy cattle by real-time TaqMan polymerase chain reaction. Vet. Immunol. Immunopathol. 77: 275-287.

Mount JA, Karrow NA, Caswell JL, Boermans HJ, et al. (2009). Assessment of bovine mammary chemokine gene expression in response to lipopolysaccharide, lipotechoic acid + peptidoglycan, and CpG oligodeoxynucleotide 2135. Can. J. Vet. Res. 73: 49-57. 
NMC (1987). Laboratory and Field Handbook on Bovine Mastitis. NMC (National Mastitis Council), Arlington.

Oviedo-Boyso J, Valdez-Alarcon JJ, Cajero-Juarez M, Ochoa-Zarzosa A, et al. (2007). Innate immune response of bovine mammary gland to pathogenic bacteria responsible for mastitis. J. Infect. 54: 399-409.

Petrovski KR, Trajcev M and Buneski G (2006). A review of the factors affecting the costs of bovine mastitis. J. S. Afr. Vet. Assoc. 77: 52-60.

Rainard P and Riollet C (2006). Innate immunity of the bovine mammary gland. Vet. Res. 37: 369-400.

Rambeaud M, Almeida RA, Pighetti GM and Oliver SP (2003). Dynamics of leukocytes and cytokines during experimentally induced Streptococcus uberis mastitis. Vet. Immunol. Immunopathol. 96: 193-205.

REST (Relative Expression Software Tool) (2009). Available at [http://www.gene-quantification.de/rest-2009.html]. Accessed July 19, 2010.

Riollet C, Rainard P and Poutrel B (2000). Differential induction of complement fragment C5a and inflammatory cytokines during intramammary infections with Escherichia coli and Staphylococcus aureus. Clin. Diagn. Lab. Immunol. 7: 161-167.

Shuster DE, Kehrli ME Jr and Stevens MG (1993). Cytokine production during endotoxin-induced mastitis in lactating dairy cows. Am. J. Vet. Res. 54: 80-85.

Shuster DE, Kehrli ME Jr, Rainard P and Paape M (1997). Complement fragment C5a and inflammatory cytokines in neutrophil recruitment during intramammary infection with Escherichia coli. Infect. Immun. 65: 3286-3292.

Singh K, Davis SR, Dobson JM, Molenaar AJ, et al. (2008). cDNA microarray analysis reveals that antioxidant and immune genes are upregulated during involution of the bovine mammary gland. J. Dairy Sci. 91: 2236-2246.

Strandberg Y, Gray C, Vuocolo T, Donaldson L, et al. (2005). Lipopolysaccharide and lipoteichoic acid induce different innate immune responses in bovine mammary epithelial cells. Cytokine 31: 72-86.

Sugimoto M, Fujikawa A, Womack JE and Sugimoto Y (2006). Evidence that bovine forebrain embryonic zinc finger-like gene influences immune response associated with mastitis resistance. Proc. Natl. Acad. Sci. U. S. A. 103: 6454-6459.

Swanson KM, Stelwagen K, Dobson J, Henderson HV, et al. (2009). Transcriptome profiling of Streptococcus uberisinduced mastitis reveals fundamental differences between immune gene expression in the mammary gland and in a primary cell culture model. J. Dairy Sci. 92: 117-129.

Takeuchi O, Hoshino K and Akira S (2000). Cutting edge: TLR2-deficient and MyD88-deficient mice are highly susceptible to Staphylococcus aureus infection. J. Immunol. 165: 5392-5396.

Tao W, Mallard B, Karrow N and Bridle B (2004). Construction and application of a bovine immune-endocrine cDNA microarray. Vet. Immunol. Immunopathol. 101: 1-17.

Vandesompele J, De Preter K, Pattyn F, Poppe B, et al. (2002). Accurate normalization of real-time quantitative RT-PCR data by geometric averaging of multiple internal control genes. Genome Biol. 3: RESEARCH0034.

Wang YH, Byrne KA, Reverter A, Harper GS, et al. (2005). Transcriptional profiling of skeletal muscle tissue from two breeds of cattle. Mamm. Genome 16: 201-210.

Yang W, Zerbe H, Petzl W, Brunner RM, et al. (2008). Bovine TLR2 and TLR4 properly transduce signals from Staphylococcus aureus and E. coli, but $S$. aureus fails to both activate NF-kappaB in mammary epithelial cells and to quickly induce TNFalpha and interleukin-8 (CXCL8) expression in the udder. Mol. Immunol. 45: 1385-1397. 